\title{
Development of sequence characterized amplified region markers from intersimple sequence repeat fingerprints for the molecular detection of toxic phytoplankton Alexandrium catenella (Dinophyceae) and pseudo- Nitzschia pseudodelicatissima (Bacillariophyceae) from French coastal waters
}

\author{
Benjamin Bornet $^{\mathrm{a}^{*}}$, Elisabeth Antoine $^{\mathrm{a}^{*}}$, Sylvaine Françoise ${ }^{\mathrm{a}}$ and Claire Marcaillou-Le Baut ${ }^{\mathrm{a}}$
}

aLaboratoire Phycotoxines et Nuisances, DEL/MP/PN, Ifremer, rue de l'lle d'Yeu, BP 21105, 44311 NANTES cedex 3, France *: Corresponding author : Authors for correspondence: e-mail bbornet@wanadoo.fr
or elisabeth.antoine@ifremer.fr.

\begin{abstract}
Harmful algal blooms are a serious threat to shellfish farming and human health all over the world. The monitoring of harmful algae in coastal waters originally involved morphological identification through microscopic examinations, which was often difficult unless performed by specialists and even then often did not permit identification of toxic species. More recently, specific molecular markers have been used to identify specific phytoplankton species or strains. Here we report on the use of the intersimple sequence repeat (ISSR) technique to develop specific sequence characterized amplified region markers (SCAR) and to identify with these tools two toxic species in French coastal waters, the diatom Pseudo-nitzschia pseudodelicatissima (Hasle) Hasle and the dinoflagellate Alexandrium catenella (Whedon and Kofoid 1936), Balech 1985. Six polymorphic ISSR regions were selected among amplified fingerprints of a representative sample of phytoplankton species. After cloning and sequencing the selected polymorphic ISSR regions, pairs of internal primers were designed to amplify a unique and specific sequence designed as a SCAR marker. Of the six selected SCAR markers, three were specific to P. pseudodelicatissima and one for A. catenella. The SCAR marker specificity was confirmed by using basic local alignment search tool comparison, by experimental assays on different strains from 11 countries, and by checking that the sequence amplified was the expected one. When tested on water samples collected along the French shores, the four specific SCAR markers proved to be efficient tools for fast and low-cost detection of toxic phytoplankton species.
\end{abstract}

Keywords: Alexandrium-; ISSR-; molecular-identification; monitoring-; Pseudo-nitzschia; SCAR- 


\section{INTRODUCTION}

Accurate and rapid identification of toxic phytoplankton species is an important challenge in the context of Harmful Algal Bloom (HAB) monitoring. HABs occur all over the world and are responsible for shellfish and fish kills and human intoxications which cause severe economic damages to the shellfish industry (Anderson 1989, Hallegraeff and Bolch 1992). At the present time, routine identification of phytoplankton is based on morphological characterization by light microscopy, which is difficult, time consuming and observer dependent.

The present work was performed to design new molecular markers for the detection of $A$. catenella and P.pseudodelicatissima, in daily monitoring. During the last decade, molecular characterization and phylogeny of phytoplankton species have mostly been based on rRNA gene analysis (Scholin et al. 1994, Medlin et al. 1998, Walsh et al. 1998, Guillou et al. 2002, Lilly et al. 2002, Edvardsen et al. 2003). However, some of these genera lacked sufficient levels of gene polymorphism and therefore the species level could not be reached. More recently RAPD, SSCP, DGGE, HMA and ISSR analysis have been used to increase the level of polymorphism detection (Adachi et al. 1997, Murayama-Kayano et al. 1998, Bolch et al. 1999, Uribe et al. 1999, Oldach et al. 2000, Coyne et al. 2001, Bornet et al., 2004). These protocols represent interesting tools for the identification and characterization of pure strains or to study genetic relationships, but they are not appropriate for routine detection of a particular target species in water samples. Thus it is important to acquire new, reproducible, specific and highly polymorphic markers, for easy use for daily analysis of toxic species in water samples.

In this study we report, for the first time, on the development and use of specific Sequence Characterised Amplified Region markers (SCAR) to identify two of the most frequent toxic species involved in HABs along the French coasts: P. pseudodelicatissima (northern part of Atlantic coasts) and A. catenella (Mediterranean sea). SCAR markers are co-dominant, mono- 
locus and PCR-based markers that require the use of two specific primers. SCAR markers are characterized by many advantages including their specificity, low cost, ease and fast use. SCAR markers have been employed with success in plant and animal species identification (Parent and Page 1998, Mariniello et al. 2002, Yau et al. 2002, Bautista et al. 2003). Usually SCAR markers have been developed from RAPD fingerprints (e.g. Parasnis et al. 2000, Koveza et al. 2001, Arnedo-Andrés et al. 2002, Bautista et al. 2003) or from AFLP fingerprints (e.g. Negi et al. 2000, Xu and Korban 2002, Schmidt et al. 2003).

Here, ISSR (Inter Simple Sequence Repeat) fingerprints (Zietkiewicz et al. 1994 or for review Reddy et al. 2002) have been selected, to develop SCAR markers, because they are known to be very reproducible, abundant, polymorphic and because of the specific targeted regions of the genomes (Zietkiewicz et al. 1994, Bornet and Branchard 2001, Bornet et al. 2002). The development of the SCAR markers was made by sequencing the selected ISSR polymorphic regions and by further definition of pairs of primers from the internal sequence of these fragments. Different tests were performed to validate the specificity and the reproducibility of SCAR markers and their efficiency in detecting toxic species in natural seawater samples was verified. The specific SCAR markers described here can be used routinely for phytoplankton monitoring.

\section{MATERIALS AND METHODS}

\section{Microalgal cultures and water samples}

Sixteen strains of Alexandrium (five A. minutum, one A. fundyense, two A. tamarense and eight A. catenella), twenty six strains of Pseudo-Nitzschia (two P. pseudodelicatissima, six P. pungens, six $P$. multiseries, three $P$. fraudulenta, five $P$. seriata, two $P$. cuspidata, one $P$. caciantha and one P. calliantha) and seventeen other strains of diatoms, dinoflagellates or 
flagellates (one Nitzschia, four Gymnodinium, three Prorocentrum, one Chaetoceros, one Isochrysis, two Skeletonema, two Tetraselmis, one Heterosigma, one Ligulodinium, and one Thalassiosira) were used. Those fifty-nine cultured strains come from 11 countries. Monoclonal cultures were maintained in Erd Schreider medium of Provasoli (ESP) (Provasoli 1968), f/2 medium (Guillard and Ryther, 1962), or ESP modified media (Amzil et al., 2001). All cultures were grown under controlled conditions: $16^{\circ} \mathrm{C}, 12 / 12 \mathrm{~h}$ light/dark photoperiod and $50+/-4$ $\mu$ mol. photons $\mathrm{m}^{-2} \cdot \mathrm{s}^{-1}$ light intensity, except for $P$. seriata strains which were grown under, 10/14h light/dark and $10^{\circ} \mathrm{C}$.

A total of twenty-seven water samples preserved with Lugol solution were analysed. Water samples were collected during the years 2002 and 2003 from the French Atlantic and Mediterranean coast. Optical observations of those samples revealed concentrations of Alexandrium and/or Pseudonitzschia cells from 0 to $2.07^{6}$ cell/L.

\section{DNA extraction}

DNA extractions of cultured microalgae were performed from mid exponential growth phase cells as described by Bornet et al. (2004). Water samples (250 ml) were filtered through PDVF membrane (Millipore, Billerica, MA USA) and DNA extractions were performed directly from the membrane with $5 \mathrm{~mL}$ of CTAB extraction buffer, as previously described for the cultures. DNA concentrations were quantified with a fluorometer (DyNA Quant 200, Hoefler, Amersham Biosciences, UK) using bisbenzimide (Hoechst 33258, Amersham Biosciences, USA) as the fluorescent dye and DNA quality was checked by agarose $(1 \%, w / v)$ electrophoresis and staining with ethidium bromide.

\section{ISSR amplifications}

Four ISSR primers $\left[(\mathrm{CAA})_{5},(\mathrm{CAG})_{5},(\mathrm{ATG})_{5},(\mathrm{GACA})_{4}\right]$ were used to amplify fingerprints, from the 59 cultured strains, as described by Bornet et al. (2004). Only polymorphic ISSR bands 
with high intensity, clear separation, a molecular weight smaller than $800 \mathrm{bp}$, and occurring solely for the targeted species were selected.

\section{SCAR markers development procedure}

Development of SCAR markers, following the procedure described in Figure 1, was inferred from the fingerprints of the diatom Pseudo-nitzschia pseudodelicatissima strain isolated in the bay of Douarnenez in 1998 by Jacqueline Fresnel (Université de Caen, France) and from the Alexandrium catenella strains ATTL01 described by Lilly et al. (2002) and isolated during the 1998 bloom in the Thau lagoon.

The selected polymorphic ISSR bands were excised from agarose gels and DNA was purified using the GeneClean kit (Bio101 inc, Vista, CA, USA). Blunt end conversion and cloning of DNA fragments were performed using the pT7Blue3 perfectly blunt kit (Novagen, Madison, WI, USA). Plasmid DNA was extracted using the Mini prep express matrix (Bio 101 inc., USA) and the length of each insert was checked by DNA digestion with EcoR I (Promega, Madison, WI, USA). Cloned DNA fragments were sequenced by Millegen Biotechnologies (Labege, France). Based on the sequence analysis of each ISSR fragments, two oligonucleotides were designed as SCAR primers. Primers were designed in order to have 1) an experimental $\mathrm{Tm}[4(\mathrm{G}+\mathrm{C})+$ 2(A+T)] equal or higher to $\left.50^{\circ} \mathrm{C}, 2\right)$ more than 19 base pairs length, 3) a $3^{\prime}$ end rich in $\mathrm{G}-\mathrm{C}$ bases. If possible, SCAR primers were selected to sit astride the SSR units corresponding to the ISSR primers and the internal sequence of each ISSR fragment. The theoretical specificity of the selected primers was tested with alignment of their sequences versus all the other ISSR sequences performed and sequences from databases using Bioedit software v5.0.9 (http://www.mbio.ncsu.edu/BioEdit/bioedit.html),. The selected primers were synthesised by Proligo (Paris, France) (Table 1). 
SCAR amplifications were performed in $12.5 \mu \mathrm{L}$ of reaction mixture containing $10 \mathrm{ng}$ of DNA, 2.7 pmol of each primer, $2.5 \mathrm{nmol}$ of $\mathrm{MgCl}_{2}, 50 \mu \mathrm{M}$ of each dNTP, 0.5 unit of Goldstar red DNA polymerase (Eurogentec, Seraing, Belgium) and $1 \mathrm{X}$ enzyme buffer. PCR conditions were $94^{\circ} \mathrm{C}$ for $6 \mathrm{~min}$, followed by 33 cycles of $94^{\circ} \mathrm{C}$ for $45 \mathrm{~s}$, annealing temperature for $45 \mathrm{~s}, 72^{\circ} \mathrm{C}$ for $60 \mathrm{~s}$ and a final elongation at $72^{\circ} \mathrm{C}$ for $120 \mathrm{~s}$. For each pair of primers, the annealing temperatures were tested using different DNAs and the highest temperatures were selected (Table 1). SCAR amplifications were analysed by electrophoresis of $5 \mu 1$ PCR products on a $2 \%(\mathrm{w} / \mathrm{v})$ agarose gel stained with ethidium bromide. The specificity of SCAR markers was tested using DNA from each cultured strains, from a mix of all the cultured strains and from seawater samples inoculated with the targeted cells; SCAR amplifications were always performed in triplicate. The amplified SCAR markers, from cultures and water samples (T3, 649, 206 and 290) were purified using the MiniElute PCR purification kit (Qiagen, Hilden, Germany) and sequenced using a CEQ 8000 Genetic Analysis system (Beckman Coulter, USA) following the manufacturer conditions. The amplified SCAR marker sequences were checked against the initial ISSR sequences using Bioedit. As a final step, the specificity of the SCAR markers were confirmed by comparison of the DNA sequences of the initial SCAR markers and the amplified fragments from positive water samples.

\section{RESULTS}

\section{SCAR selection and validation}

Four specific ISSR fragments for P. pseudodelicatissima and two for A. catenella were selected from the ISSR fingerprints. No similarities were observed between the sequences of the ISSR fragments and sequences from the database (using NCBI Blast search). No homologies were observed between sequences of each selected SCAR primers versus themselves or versus 
sequences from databases. Internal primers deduced from these six ISSR fragments led to the design of three SCAR markers (681, 431 and 731) for P. pseudodelicatissima and one SCAR marker (674) for A. catenella amplifying a single band for each primer pair. Sequences of the SCAR markers, 431, 681, 731 and 674, are available in Genbank with the accession numbers: AY653033, AY653034, AY653035 and AY653036, respectively.

The optimal annealing temperature was $62^{\circ} \mathrm{C}$ for SCAR 681, 431, 731 and $63^{\circ} \mathrm{C}$ for SCAR 674 (Table 1). These SCAR markers corresponded to 283, 487, 459 and 263 bp PCR products, respectively (Figure 2). Two other SCAR markers identified were not selected because SCAR 685 amplified multiple bands in P. pseudodelicatissima species and SCAR 566 amplified a single band in A. catenella but also in two other species (Skeletonema costatum and Tetraselmis suesica). Using the four selected markers, no cross amplifications were observed with the other 59 cultured strains, closely related or not to the targeted species (Figure 2). SCAR markers were also amplified with success from a mix of all the 59 cultured strains amended with either $P$. pseudodelicatissima or A. catenella in different proportions. The four amplified SCAR markers were sequenced and did not show differences with the sequence of the ISSR used to develop them.(Figure 3). Similarly, SCAR primers 431, 681 and 731, with the same annealing temperature, were tested in a multiplex SCAR-PCR assay with DNA from of all the cultured strains. The three bands corresponding to the three SCAR markers were obtained only from $P$. pseudodelicatissima strains.

Water samples analysis

Multiplex and single SCAR PCR were used to detect P. pseudodelicatissima and A. catenella species, respectively, from 27 water samples from different geographical areas of the French coast. Each PCR reaction was monitored with a negative control and two positive controls, the 
latter consisting of cultured strains and water samples inoculated with A. catenella or $P$.

pseudodelicatissima to exclude the possibility of PCR inhibitions by seawater. For each PCR, no amplification was observed for the negative control while all four specific SCAR markers were successfully amplified from the positive controls. SCAR markers were successfully amplified from water samples seeded with 30,000 cells . L-1 of P. pseudodelicatissima and 100,000, 1000, 500 , or 250 cells . L-1 of A. catenella, which corresponded to DNA extraction from 7500 or 25,000, 250, 125, and 63 cells (DNA extraction from $250 \mathrm{~mL}$ ) and the amount of DNA in each PCR reaction corresponded to 1000 cells of $P$. pseudodelicatissima and to $126,30,16$, and 8 cells of A. catenella (Figure 4).

Among the 27 tested water samples, positive results were found using SCAR markers from the following seven stations (Figure 5): $\mathrm{n}^{\circ} 216$ (Camaret, France, 06-2002), ${ }^{\circ} 649$ (Thau, France, 10-2003), T3 (Thau, France, 10-2003), 823-1 (Thau, France, 10-2003), 823-2 (Thau, France, 102003), nº 206 (Glénan, France, 05-2003) and nº 290 (Men Du, France, 06-2003). Markers 431, 731 and 681 led to the detection of $P$. pseudodelicatissima species in the water sample numbered 216, 206 and 290 from the Finistère coast (North Atlantic) and the SCAR marker 674 detected the strain A. catenella in water samples numbered 649, T3, 823-1, 823-2 collected during a bloom that occurred in October 2003 in the Thau lagoon. No SCAR markers were amplified from the 20 remaining water samples. Sequence identity of the SCAR markers amplified from the cultured targeted strains and the SCAR markers amplified from the field water samples was confirmed by DNA sequencing of the PCR products (Figure 3).

\section{DISCUSSION}

Here we have shown for the first time that ISSR fingerprints are suitable starting points to develop SCAR markers to identify toxic phytoplankton species from water samples. These 
fingerprints presumably are effective because their abundance and the very high polymorphic level of ISSR fingerprints between phytoplankton strains (Bornet et al., 2004). For the two targeted species, six ISSR markers were selected and four gave species-specific SCAR markers. The selected criteria used to develop the primers flanking the SCAR markers led to high specificity and reproducibility, where reproducibility was confirmed by performing each PCR (from the 59 cultured strains and from water samples) in triplicate. The specificity and accuracy of the SCAR markers were further confirmed with DNA of cultured strains, seeded seawater samples, and natural seawater samples. When tested against 59 strains, corresponding to 12 genera from 11 countries, positive amplification solely occurred with the DNA of the targeted species. Specificity was confirmed by comparison of the DNA of the internal sequences of ISSR fragments and the sequences of the amplified SCAR markers. Both SCAR markers amplified from cultured strains and those amplified from positive seawater samples showed high sequence identities with the internal sequence of the ISSR fragment used to develop them. In conclusion, the selected primers were specific and amplified only the targeted region of the selected genome species.

A. tamarense, A. catenella and A. fundyense form a group, called the "tamarensis complex" in terms of morphological similarities. Neither immunological assays nor molecular studies (rDNA) provided specific markers for these species (Adachi et al. 1993a, Adachi et al. 1993b, Scholin and Anderson 1993). Therefore, the SCAR marker 674, for which the specificity has been verified, reveals promise as a new molecular marker to distinguish A. catenella from the closely related species. When using this marker to detect $A$. catenella in sea water samples collected from the French coast, no SCAR amplifications were obtained for the water samples from the north Atlantic coast, although in nine of the samples Alexandrium spp. were counted at an 
abundance of 100 to 2,070000 cells $\bullet \mathrm{L}^{-1}$. These results were in agreement with the fact that $A$. catenella has never been observed in Atlantic waters and confirmed the specificity of the $A$. catenella SCAR marker which did not cross react with the Atlantic Alexandrium species. Water samples 649, 1480, T3, 823-1 and 823-2 were collected in the Thau lagoon where toxic events revealed the occurrence of Alexandrium spp. related to the tamarensis complex (Abadie et al. 1999), recently identified as A. catenella (Lilly et al. 2002). Microscopic observations of those samples have denoted the presence of chains from 2 to 6 cells indicating that the toxic event was probably due to A. catenella. SCAR marker 674 was amplified in 4 out of the 5 samples, confirming that the species occurring during the HAB event in Thau lagoon was $A$. catenella.

SCAR markers 431, 731, and 681 were found to be specific to Pseudo-nitzschia pseudodelicatissima. The detection of P.pseudodelicatissima by multiplex PCR was feasible, which enhanced the specificity of the detection and reduced the time and cost of each analysis. Optical observations were not sufficient to distinguish the Pseudo-nitzschia species but allowed us to classify them in accordance with the size of the cells. In this manner P. pseudodelicatissima and P. delicatissima species were assigned to the group of "narrow cells" ( $<4 \mu \mathrm{m}$ width). Narrow cells were observed in water samples 206, 290, 558 and 559 and positive SCAR amplifications in samples 206 and 290 indicated that in these samples the narrow cells were $P$. pseudodelicatissima. In samples 558 and 559 the narrow cells observed could correspond to $P$. delicatissima.

The French national monitoring network has selected the following values: 100,000 cells $\bullet \mathrm{L}^{-1}$ of Pseudo-nitzschia spp. and 1,000 cells $\bullet \mathrm{L}^{-1}$ of A. catenellalA. tamarense species as warning thresholds. SCAR markers were easily amplified from seawater inoculated respectively with 
30,000 cells $\bullet \mathrm{L}^{-1}$ of $P$. pseudodelicatissima and $100,000,1,000,500$ and 250 cells $\bullet \mathrm{L}^{-1}$ of $A$.

catenella. We were thus able to detect the two targeted species at lower concentrations than those used for the warning thresholds. In sample 216, where no Pseudo-nitzschia cells were observed, SCAR analysis gave a positive signal for this species. This result showed the vulnerability of the classical microscope method used by the monitoring network (observation of a $10 \mathrm{~mL}$ sedimentation chamber) and the better accuracy of molecular detection. Because samples have to be filtered, or can be centrifuged, before nucleic acid extractions, larger volumes of seawater can be processed for a single assay. In this way cells occurring in low concentration can be detected in a quick and effective manner.

Overall, this study showed the usefulness of SCAR markers over microscopic observations for routine monitoring of HAB species. SCAR markers were able to quickly discriminate and detect toxic phytoplankton species when microscopic analysis could only discriminate between genera without differentiating toxic from non-toxic species. The SCAR markers based on PCR amplifications supply quick, easy to use, and low-cost DNA markers to detect toxic phytoplankton species. They offer an interesting alternative to the use of rRNA molecular probes and to the FISH whole cell hybridization assays (e.g. Parsons et al. 1999, Tyrrell et al. 2001, John et al. 2003), particularly to analyse seawater samples where the particle load can induce false responses. In this technique, the detection with classical molecular probes is dependent on the fluorochrome type, the stringency of the reaction used and also on the sample component (Bouvier and del Giorgio, 2003). Because of the universality of ISSR markers and their unlimited number, detection of phytoplankton species via SCAR markers can be enlarged to every toxic or non toxic cultured species. For non cultured species, like Dinophysis ones, the development of SCAR markers will require extraction and amplification of DNA from single isolated cells, for example using the DNA extraction protocol developed by Marín et al. (2001) 
or by trying DNA extraction procedure developed for forensic analysis (e.g. FTA technology, Whatman inc). The design of SCAR markers for other toxic species threatening the French coasts is under investigation as well as the use of SCAR markers for real time PCR that will allow simultaneous identification and quantification of phytoplankton species.

The authors thank Stephen Bates, Claude Léger, Nina Lundholm, and Santiago Fraga for the strains they have kindly provided. The authors are very grateful to Elisabeth Nézan who examined the Atlantic coast samples, to Patrick Lassus who examined the Thau lagoon samples and to the members of the Ifremer coastal laboratory Morbihan-Pays de Loire who have kindly provided water samples. 


\section{References}

Abadie, E., Amzil, Z., Belin, C., Comps, M.-A., Elziere-Papayanni, P., Lassus, P., Le Bec, C., Marcaillou-Le Baut, C., Nezan, E. \& Poggi R. 1999. Contamination de l'étang de Thau par Alexandrium tamarense : Episode de novembre à décembre 1998. Ifremer [Ed.], Plouzané (France).

Adachi, M., Sako, Y. \& Ishida Y. 1993a. Application of monoclonal antibodies to field samples of Alexandrium species. Nippon Suisan Gakkaishi 59: 1171-5.

Adachi, M., Sako, Y., Ishida, Y., Anderson, D.M. \& Reguera B. 1993b. Cross-reactivity of five monoclonal antibodies to various isolates of Alexandrium as determined by an indirect immunofluorescence method. Nippon Suisan Gakkaishi 59: 1807.

Adachi, M., Sako, Y. \& Ishida Y. 1997. Analysis of Gymnodinium catenatum (Dinophyceae) using sequences of the 5.8S RDNA-ITS regions and random amplified polymorphic DNA. Fish. Sci. 63: 701-7.

Amzil Z., Fresnel J., Le Gal D. \& Billard C. 2001. Domoic acid accumulation in French shellfish in relation to toxic species of Pseudo-nitzschia multiseries and P. pseudodelicatissima. Toxicon, 39: $1245-1251$ 
Anderson D.M. 1989. Toxic algal blooms and red tides: a global perspective, p. 11-16. In T.

Okaichi, D.M. Anderson, and T. Nemoto (ed.), Red tides: biology, environmental science and toxicology. Elsevier, New York, N.Y.

Arnedo-Andrés, M.S., Gil-Ortega, R., Luis-Arteaga, M. \& Hormaza J.L. 2002. Development of RAPD and SCAR markers linked to the Pvr4 locus for resistance to PVY in pepper (Capsicum annuum L.). Theor. Appl. Genet. 105: 1067-4.

Bautista, R., Crespillo, R., Canovas, F.M. \& Claros M.G. 2003. Identification of olive-tree cultivars with SCAR markers. Euphytica 129: 33-1.

Bolch, C.J.S., Blackburn, S.I., Hallegraeff, G.M. \& Vaillancourt R.E. 1999. Genetic variation among strains of the toxic dinoflagellate Gymnodinium catanatum (Dinophyceae). J. Phycol. 35: $359-7$.

Bornet, B. \& Branchard M. 2001. Nonanchored Inter Simple Sequence Repeat (ISSR) markers: reproducible and specific tools for genome fingerprinting. Plant Mol. Biol. Rep. 19: 209-5.

Bornet, B., Muller, C., Paulus, F. \& Branchard M. 2002. High informative nature of Inter Simple Sequence Repeat (ISSR) sequences amplified with tri- and tetra-nucleotide primers from cauliflower (Brassica oleracea var. botrytis L.) DNA. Genome 45: 890-6.

Bornet B., Antoine E., Bardouil M. \& Marcaillou-Le Baut C. ISSR as new markers for genetic characterization and evaluation of relationships among phytoplankton. J. Appl. Phycol.16: 285-0. 
Bouvier, T. \& Del Giorgio P.A. 2003. Factors influencing the detection of bacterial cells using fluorescence in situ hybridization (FISH): a quantitative review of published reports. FEMS Microbiol. Ecol. 44: 3-5.

Coyne, K.J., Hutchins, D.A., Hare, C.E. \& Cary S.C. 2001. Assessing temporal and spatial variability in Pfiesteria piscicida distributions using molecular probing techniques. Aqua. Microb. Ecol. 24: 275-5.

Edvardsen, B., Shalchian-Tabrizi, K., Jakobsen, K.S., Medlin, L. K., Dahl, E., Brubak, S. \& Paasche E. 2003. Genetic variability and molecular phylogeny of Dinophysis species (Dinophyceae) from Norwegian waters inferred from single cell analyses of rDNA. J. Phycol. 39: $395-8$.

Guillard, R.R.L. \& Ryther J.H. 1962. Studies on marine planktonic diatoms. 1 Cyclotella nana Hustedt and Detonula confervacea (Cleve) Gram. Can. J. Microbiol. 8: 229-9.

Guillou, L., Nezan, E., Cueff, V., Erard-Le Denn, E., Cambon-Bonavita, M.A., Gentien, P. \& Barbier G. 2002. Genetic diversity and molecular detection of three toxic dinoflagellate genera (Alexandrium, Dinophysis, and Karenia) from French coasts. Protist 153: 223-8. 
Hallegraeff, G.M. \& Bolch C.J. 1992. Transport of diatom and dinoflagellate resting spores via ship's ballast water: implication for plankton biogeography and aquaculture. J. Plankton Res. 14:1067-4.

John, U., Cembella, A., Hummert, C., Elbrächter, M., Groben, R. \& Medlin L. 2003.

Discrimination of the toxigenic dinoflagellates Alexandrium tamarense and A. ostenfeldii in cooccurring natural populations from Scottish coastal waters. Eur. J. Phycol. 38 :25-0.

Koveza, O.V., Kokaeva, Z.G., Gostimsky, S.A., Petrova, T.V. \& Osipova E.S. 2001. Creation of a SCAR Marker in Pea Pisum sativum L. Using RAPD Analysis. Russ. J. of Genet. 37: 464-6.

Lilly, E.L., Kulis, D.M., Gentien, P. \& Anderson D.M. 2002. Paralytic shellfish poisoning toxins in France linked to a human-introduced strain of Alexandrium catenella from the western Pacific: evidence from DNA and toxin analysis. J. Plankton Res. 24: 443-2

Marín I., Aguilera, A., Reguera B. \& Abad J.P. 2001. Preparation of DNA suitable for PCR amplification from fresh or fixed single Dinoflagellate cells. BioTechniques, 30: 88-3.

Mariniello, L., Sommella, M.G., Sorrentino, A., Forlani, M. \& Porta R. 2002. Identification of Prunus armeniaca cultivars by RAPD and SCAR markers. Biotechnology Letters 24: 749-5.

Medlin, L.K., Lange, M., Wellbrock, U., Donner, G., Elbräter, M., Hummert, C. \& Luckas B. 1998. Sequence comparisons link toxic European isolated of Alexandrium tamarense from the Orkney Islands to toxic North American stocks. Europ. J. Protistol. 34: 329-5. 
Murayama-Kayano, E., Yoshimatsu, S., Kayano, T., Nishio, T., Ueda, H. \& Nagamune T. 1998. Application of the random amplified polymorphic DNA (RAPD) technique to distinguishing species of the red tide phytoplankton Chattonella (Raphidophyceae). J. Ferm. Bioeng. 85: 343-5.

Negi, M.S., Devic, M., Delseny, M. \& Lakshmikumaran M. 2000. Identification of AFLP fragments linked to seed coat colour in Brassica juncea and conversion to SCAR markers for rapid selection. Theor. Appl. Genet. 101: 146-2.

Oldach, D.W., Delwiche, C.F., Jakobsen, K.S., Tengs, T., Brown, E.G., Kempton, J.W., Schaeffer, E.F., Bowers, H.A., Glasgow, H.B., Burkholder, J.M., Steidinger, K.A. \& Rublee P.A. 2000. Heteroduplex mobility assay-guided sequences discovery: elucidation of the small subunit (18S) rDNA sequences of Pfiesteria piscicida and related dinoflagellates from complex algal culture and environmental sample DNA pools. Proc. Natl. Acad. Sci. USA 97: 4303-8.

Parasnis, A.S., Gupta, V.S., Tamhankar, S.A. \& Ranjekar P.K. 2000. A highly reliable sex diagnostic PCR assay for mass screening of papaya seedling. Mol. Breed. 6: 337-4.

Parent, J.G. \& Page D. 1998. Identification of raspberry cultivars by sequence characterized amplified region DNA analysis. Hort. Science 33:140-2.

Parsons, M.L., Scholin, C.M, Miller, P.E., Doucette, G.J., Powell, C.L., Fryxell, G.A., Dortch, Q. \& Soniat T.M. 1999. Pseudo-nitzschia species (Bacillariophyceae) in Louisiana coastal waters: molecular probe field trials, genetic variability, and domoic acid analyses. J. Phycol. 35: 1368-8. 
Provasoli, L. 1968. Media and prospects for the cultivation of marine algae. pp. 63-75. In Watanabe, A. and Hattori, A. [Ed.] Cultures and Collections of Algae. Proc. U.S.-Japan Conf. Hakone, Japan, September 1966. Publ. by the Jap. Soc. Plant Physiol.

Reddy, M.P., Sarla N. \& Siddiq E.A. 2002. Inter simple sequence repeat (ISSR) polymorphism and its application in plant breeding. Euphytica 128: 9-7.

Schmidt, H., Ehrmann, M., Vogel, R.F., Taniwaki, M.H. \& Niessen L. 2003. Molecular Typing of Aspergillus ochraceus and Construction of Species Specific SCAR-Primers Based on AFLP. Syst. and Appl. Microbil. 26: 138-6.

Scholin, C.A., Herzog, M., Sogin, M. \& Anderson D.M. 1994. Identification of group- and strain-specific genetic markers for globally distributed Alexandrium (Dinophyceae). II. Sequence analysis of a fragment of the LSU rRNA gene. J. Phycol. 30: 999-1.

Scholin, C.A. \& Anderson D.M. 1993. Population analysis of toxic and non-toxic Alexandrium species using ribosomal RNA signature sequences. Toxic Phytoplankton Blooms in the sea, T.J. Smayda and Y. Shimizu [Ed.], Elsevier science publishers, pp 95-2.

Scholin, C.A., Hallergraeff, G.M. \& Anderson D.M. 1995. Molecular evolution of the Alexandrium tamarense 'species complex' (Dinophyceae): dispersal in the north American and West Pacific regions. Phycologia 34: 472-5. 
Tyrrell, J.V., Bergquist, P.R., Bergquist, P.L \& Scholin C.A. 2001. Detection and enumeration of Heterosigma akashiwo and Fibrocapsa japonica (Raphidophyceae) using rRNA-targeted oligonucleotide probes. Phycologia 40: 457-7.

Uribe, P.C., Suarez-Isla, B.A. \& Espejo R.T. 1999. Ribosomal RNA heterogeneity and identification of toxic dinoflagellate cultures by heteroduplex mobility assay. J. Phycol. 35: 8848.

Walsh, D., Reeves, R.A., Saul, D.J., Gray, R.D., MacKenzie, L., Bergquist, D. \& Bergquist P.L. 1998. Heterogeneity of SSU and LSU rDNA sequences of Alexandrium species. Biochem. Syst. Ecol.26: 495-9.

Xu, M. \& Korban S.S. 2002. AFLP-derived SCARs facilitate construction of a $1.1 \mathrm{Mb}$ sequenceready map of a region that spans the Vflocus in the apple genome. Plant Mol. Biol. 50: 803-8.

Yau, F.C.F., Wong, K.L., Shaw, P.C., But, P.P.H. \& Wang J. 2002. Authentication of snakes used in Chinese medicine by sequence characterized amplified region (SCAR). Biodiversity and conservation 11: 1653-2.

Zietkiewicz, E., Rafalski, A. \& Labuda D. 1994. Genome fingerprinting by simple sequence repeat (SSR)-anchored polymerase chain reaction amplification. Genomics 20: 176-3. 
TABLE 1: Characteristics of the SCAR primers developed to detect cells of two toxic phytoplankton strains.

\begin{tabular}{|c|c|c|c|c|c|}
\hline $\begin{array}{l}\text { SCAR } \\
\text { marker }\end{array}$ & $\begin{array}{c}\text { ISSR } \\
\text { primer }^{\text {a }}\end{array}$ & $\begin{array}{l}\text { Primers sequences for } \\
\text { SCAR amplifications }\end{array}$ & Targeted species & $\mathbf{T m}^{b}$ & $\mathbf{T a}^{\mathrm{c}}$ \\
\hline 431 & $(\mathrm{CAA})_{5}$ & $\begin{array}{l}\text { CAACAACAATACTGACAGCAGC } \\
\text { CAACAACACGTCTTTGGTTTCC }\end{array}$ & P. pseudodelicatisima & $\begin{array}{l}50 \\
54\end{array}$ & 62 \\
\hline 681 & $(\mathrm{ATG})_{5}$ & $\begin{array}{l}\text { GTCAACGAAAAGCATTCTGGG } \\
\text { AGGACGAAAAGGAAGATGGC }\end{array}$ & P. pseudodelicatisima & $\begin{array}{l}54 \\
60\end{array}$ & 62 \\
\hline 731 & $(\mathrm{GACA})_{4}$ & $\begin{array}{l}\text { CTTGTCATGTCATTCGAACGGC } \\
\text { AATCCATTCATCATGACGACGG }\end{array}$ & P. pseudodelicatisima & $\begin{array}{l}57 \\
56\end{array}$ & 62 \\
\hline 674 & $(\mathrm{ATG})_{5}$ & $\begin{array}{l}\text { ATGATGATCATGATGCGTTGGC } \\
\text { ATGATGGCGATGACGACAACTC }\end{array}$ & A. catenella & 57 & 63 \\
\hline
\end{tabular}

${ }^{\text {a }}$ Sequence of the ISSR primer used to amplify polymorphic bands selected to develop the SCAR markers

${ }^{\mathrm{b}}$ Theoretical annealing temperature $(\mathrm{Tm}=[4(\mathrm{G}+\mathrm{C})+2(\mathrm{~A}+\mathrm{T})])$

${ }^{\mathrm{c}}$ Optimal annealing temperature 
FIG 1: Diagram of the procedure to develop SCAR markers, from ISSR fingerprints, and to use them for the detection of toxic phytoplankton.

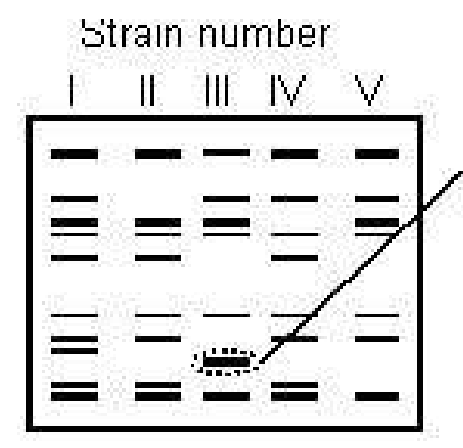

ISSR fingerprints

Sea water samples<smiles>[CH]1CC1</smiles>

Samples filtration<smiles>C[13CH]</smiles>

DNA extraction from each filter<smiles>[CH][CH]</smiles>

PCR with the SCAR primers

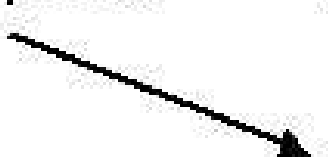

In silico validation of the specificity of each primer

DNA purification from the electrophoresis matrix

Cloning and sequencing of the selected fragments

Selection of two PCR primers from the internal sequence of the ISSR fragment
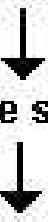

Validation of the primer's specificity by PCR with DNA of different species

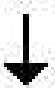

Final validation of the specificity of the selected SCAR markers by comparison of the sequence of the amplified SCAR and the sequence of the ISSR used to develop it

Test of the efficiency of the SCAR markers to detect the targeted species from inoculated sea water and from sea water samples

Sea water samples

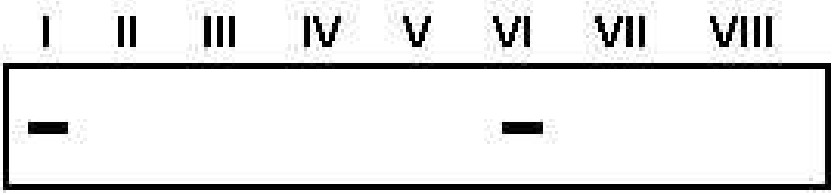

Presence of the targeted specie in samples I and VI 
FIG 2: Amplification of SCAR markers on DNAs from different phytoplankton species

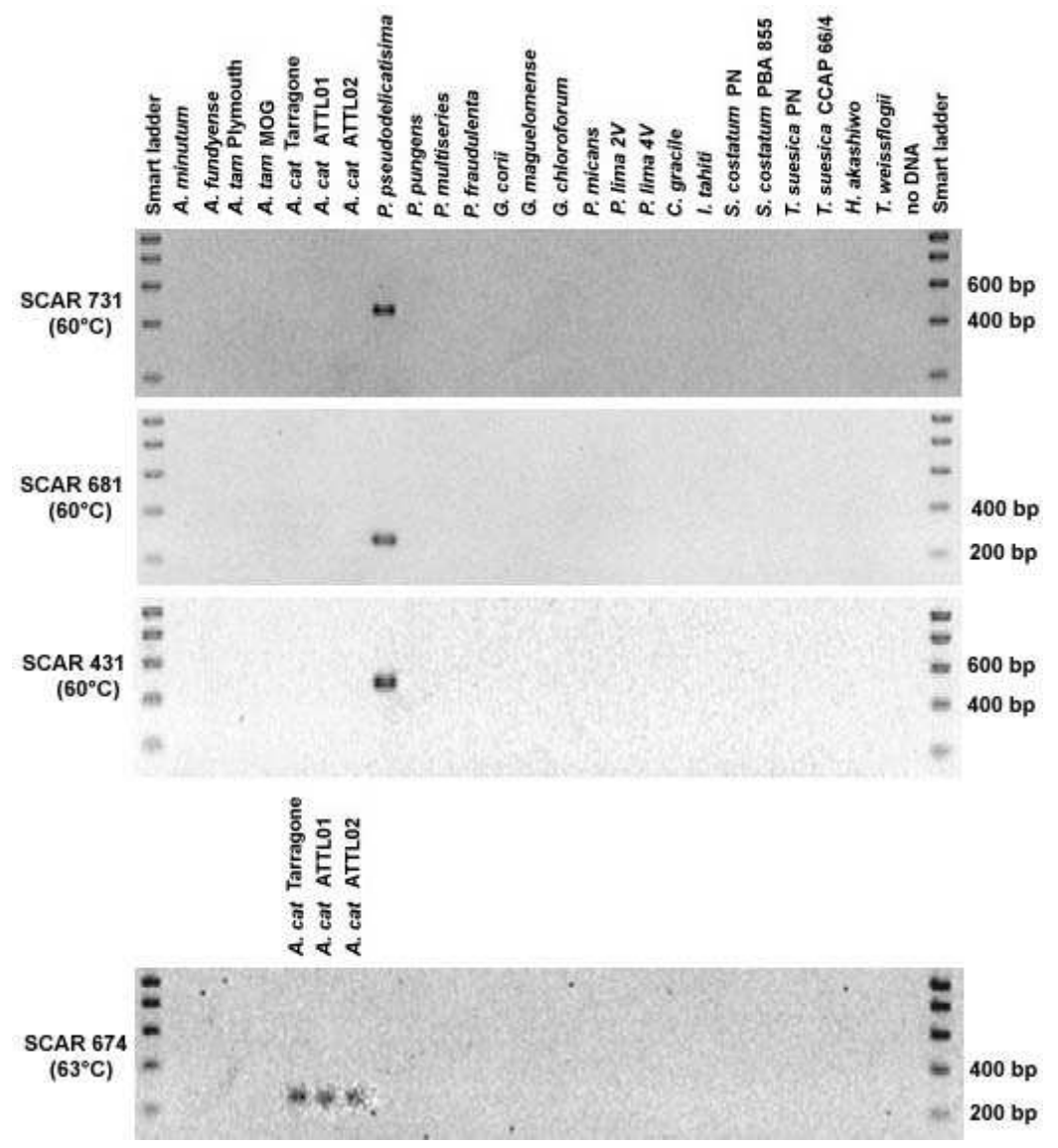


FIG 3: DNA comparison between sequences of the ISSR fragment and amplified SCAR markers

674 from cultured targeted strain and sea water samples number 649 and T3.

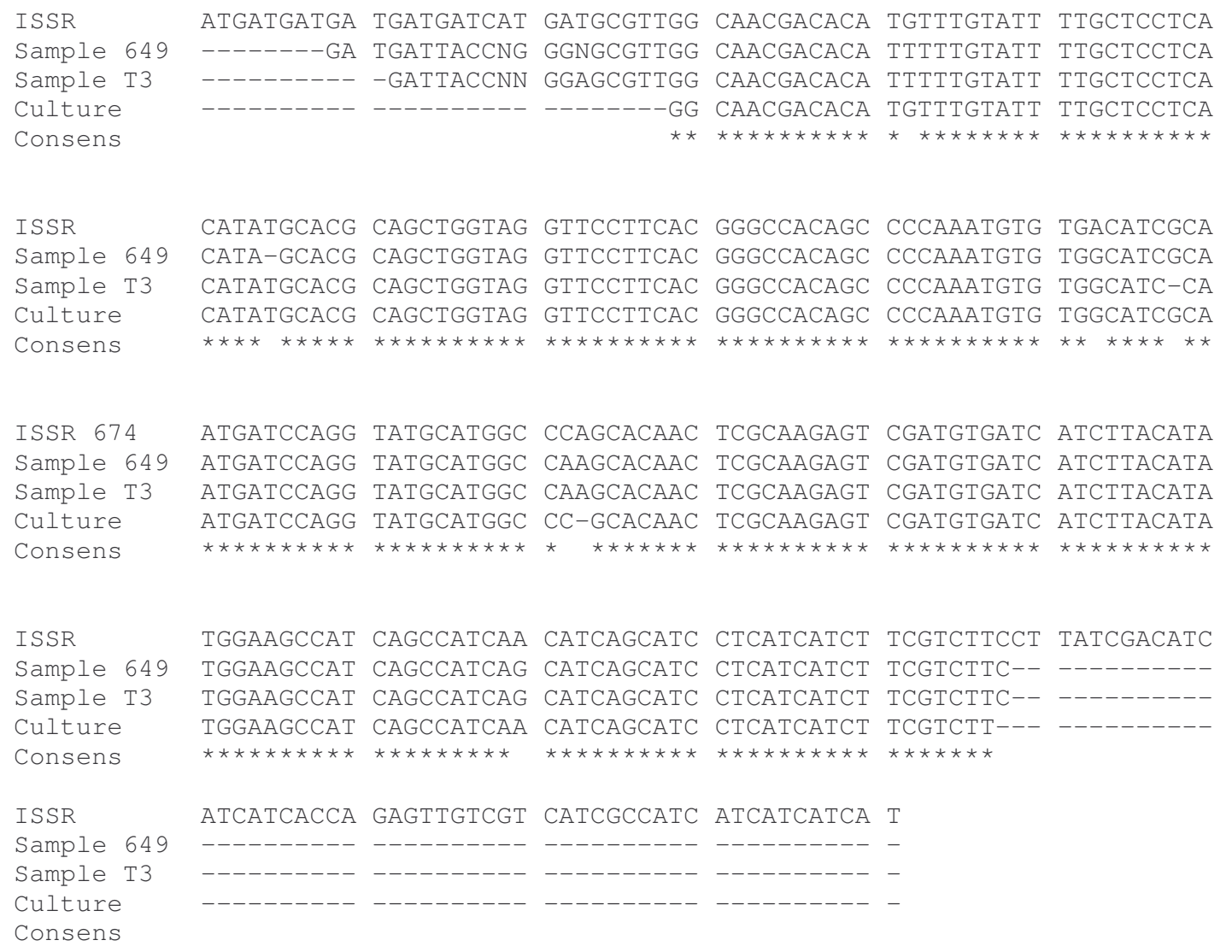


FIG 4: Amplification of SCAR marker 674 with different concentrations of cultured A. catenella

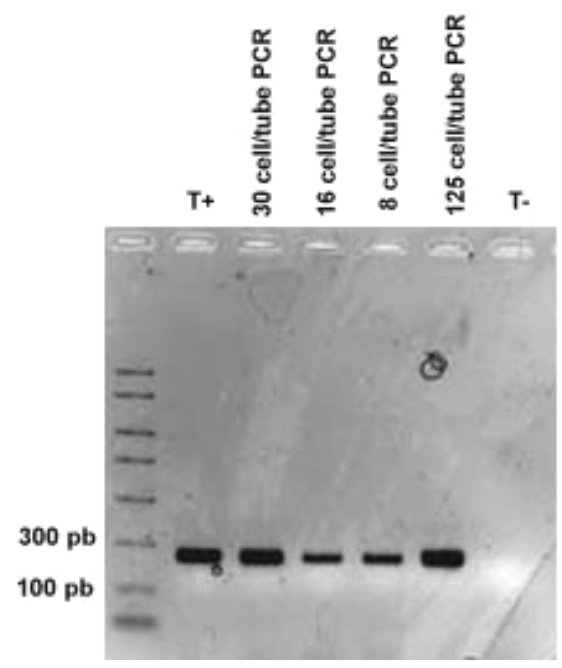


FIG 5: Amplification of SCAR markers for the detection of toxic phytoplankton species $(A$. catenella and P. pseudodelicatissima) in water samples from French coast.

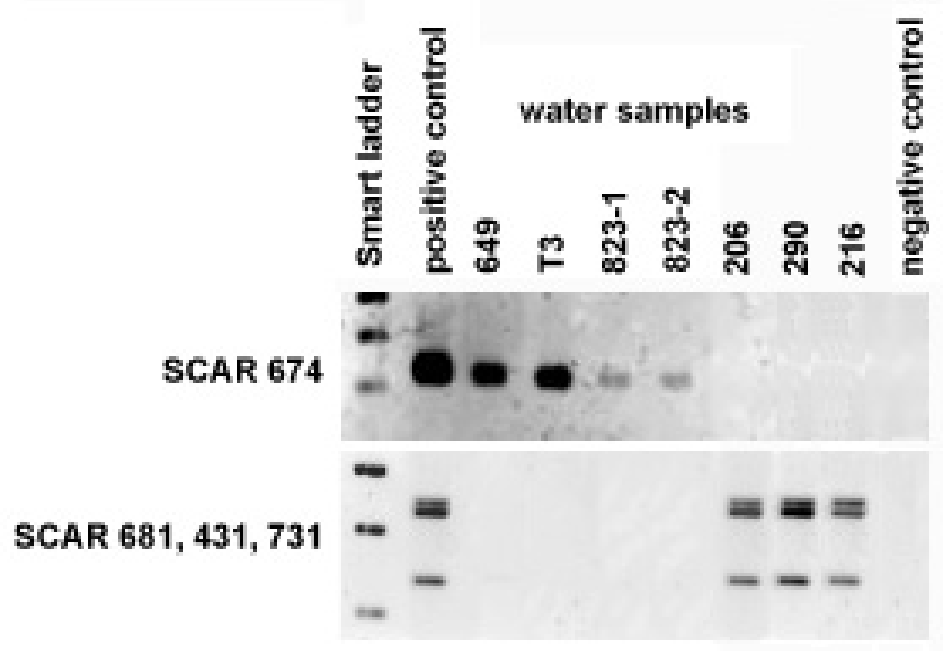

